\title{
PREPARING A TEACHER FOR INNOVATIVE ACTIVITIES AS A MECHANISM FOR UPDATING PEDAGOGICAL EDUCATION
}

\author{
Guljakhon Karlibaeva
}

Dsc Nukus State Pedagogical Institute Named After Ajiniyaz, Uzbekistan

\section{ABSTRACT}

The article discusses the issues of enhancing the learning process, increasing the efficiency of the lesson using innovative methods necessary in the future and professional activities of future physics teachers.

KEYWORDS: - lifelong education, future physics teachers, interactive learning, lesson efficiency, methodological training, competence.

\section{INTRODUCTION}

Recently, one of the main trends in the development of education in the world is to improve its quality on the basis of personality development. This trend is typical for most developed countries, and in support of the implementation of the new educational policy, the governments of these countries are adopting appropriate legislative acts, which reflect, among other things, the issues of restructuring the system of training teachers.

\section{T HE MAIN RESULTS AND FINDINGS}

The main goal of modern vocational education is as follows:

- training of qualified specialists who are competitive in the labor market, competent, responsible, professionally mobile, fluent in their profession and focused on activities in related fields, capable of effective work at the level of world standards, ready for continuous professional growth;

- meeting the needs of the individual in obtaining education;

- meeting the requirements of the modern labor market [4].

By the innovative readiness of a future teacher, we mean his theoretical, practical and psychophysiological level in mastering the full content of pedagogical innovation in the context of lifelong education. In the process of implementing innovative activities, all the knowledge, abilities and skills, as well as the personality traits obtained by teachers during the course of academic subjects at the pedagogical university, are concretized and 
CURRENT RESEARCH JOURNAL OF PEDAGOGICS 2(8): 52-57, August

2021 DOI: https://doi.org/10.37547/pedagogics-crjp-02-08-12

ISSN 2767-3278

(C)2021 Master Journals

Crossref dof 81 Google

Accepted $26^{\text {th }}$ August, 2021 \& Published 31 th August, 2021

implemented in practice.

In pedagogical science today there are theoretical and practical prerequisites, which must be taken into account when implementing the training of future teachers capable of innovative activities.

Firstly, this is a huge, constantly growing and far from filled niche in the labor market, which requires specialists in the development and implementation of innovative educational technologies of various types and levels, starting with the development and implementation of a set of correctional and developmental exercises for students with certain special needs. and ending with the construction of training programs for various groups that require quality design and practical implementation.

Secondly, it is the presence of relevant developments in domestic and foreign psychological and pedagogical science and their approbation in the field of pedagogical innovation.
The main goal of innovative teaching technologies is to enhance the learning process. It can be achieved in different ways, in particular, due to the special organization of the educational material, its concentration and distribution, specific teaching methods, the organization of the interaction of students in a group, as well as due to the mobilization and more productive use of the potential capabilities of the teacher and student, and their interaction in the educational process. The activity of the participants in the educational process is expressed in their maximum involvement in the learning process. The use of technical teaching aids, computer programs, thematic video and audio materials significantly affects the learning process, contributes to the activation of educational activities [2].

Currently, the university widely uses a variety of methods of active learning in the educational process. The most common ones are shown in Figure 1. 


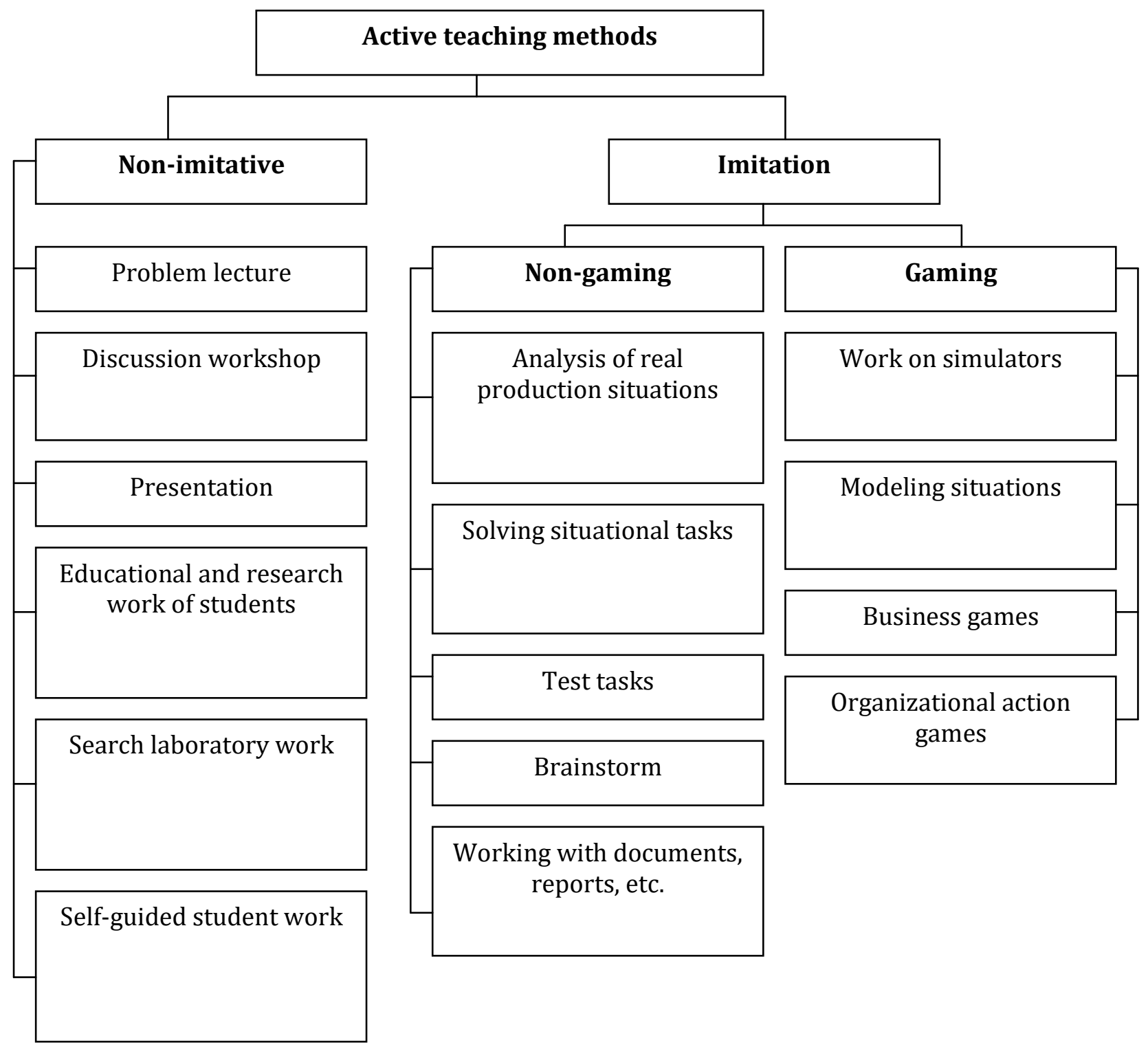

Figure 1. Classification of active teaching methods.

Among the priority areas of teacher training for innovative activities are:

- analysis of the development of innovative processes in education, examination and monitoring of the level of development of the components of innovative education (environment, educator, trainees), assessment of educational programs, participation in their development, determination of their effectiveness; 
CURRENT RESEARCH JOURNAL OF PEDAGOGICS 2(8): 52-57, August

2021 DOI: https://doi.org/10.37547/pedagogics-crjp-02-08-12

ISSN 2767-3278

(C)2021 Master Journals

\section{Crossref do) 81 Google}

Accepted 26 $6^{\text {th }}$ August, 2021 \& Published 31 ${ }^{\text {th }}$ August, 2021

- selection of adequate methods for diagnosing the level of personal and cognitive development of students, secondary and higher educational institutions included in the system of innovative education;

- diagnostics of the degree of development of professionally important qualities of a future specialist, social maturity, pedagogy, methodology for developing an innovative project;

- a system for managing innovative processes in education;

- individualization and differentiation of the educational process in the system of innovative education, etc.

Speaking about the specific experience of introducing and using innovations in the work of a physics teacher, it is necessary, first of all, to note that the relatively successful implementation of this process is facilitated by the teacher's self-improvement in various fields of education, this is the use of new information technologies in the learning process, the use of a local network in the classroom, the use of lessons of an interactive whiteboard, creation of a personal website.

One of the relevant areas of pedagogical training is the development of the personality of a future specialist, which ensures adaptability to the changing socio-cultural conditions of the educational space. The versatility of personality development can be ensured by the implementation in organizational work with students of integrative types of educational activities that affect the disclosure of the potential of future specialists and self-realization in the teaching profession.

In our study, special attention is paid to the role of organizing and managing student learning using play activities in the pedagogical process of the university. Analysis of research on the problem of game activity as a psychological and pedagogical category made it possible to single out its main characteristics: independent activity, a system of actions for the implementation and assessment of the game process, overprofessional and professional activities, integrative activities, game management activities, activities to activate subjects, management activities, creative process. [1. p. 20].

The use of didactic games in teaching helps to improve the quality of knowledge, better assimilation and consolidation of educational material, teaches us to highlight the main thing, to generalize. The assimilation of the material during the game does not require voluntary memorization, increases its emotional perception, avoids overloading students. The game reduces the psychological stress that arises in the classroom, built in a traditional way. The results of the game provide feedback, give the teacher the necessary information to correct the knowledge and skills of students [4].

Taking into account the role of play in teaching and educating students, we set the goal of our research - to study the methods of preparing students in the classroom according to the methodology of teaching physics for the use of gaming technologies in teaching physics at school.

The implementation of game activity in teaching students is ensured by the following requirements for it:

- organized as a relatively independent and variable;

- viewed as integrative, managerial and creative;

- various elements of the learning environment (didactic tools) are used to interact with students.

The logic of the stage-by-stage design of game 
CURRENT RESEARCH JOURNAL OF PEDAGOGICS 2(8): 52-57, August

2021 DOI: https://doi.org/10.37547/pedagogics-crjp-02-08-12

ISSN 2767-3278

(C)2021 Master Journals

Crossref do: 81 Google

Accepted $26^{\text {th }}$ August, 2021 \& Published 31 th August, 2021

activity involves the identification of individual differences among students (interactivity) and the development, on this basis, of strategies for organizing their pedagogical training that implement the concept of game learning.

At the first stage of pedagogical training, the main attention is paid to the formation of an appropriate group of playing skills, methods of creative play activity and ideas about the specifics of the teacher's play position when organizing learning on a play basis, as well as fostering an emotional-value attitude to play culture in general. At the next stage - the development of an integral system of knowledge (factual, conceptual, procedural and technological) about the game, the development of experience in performing social roles and functions, the education of cognitive independence. The next stage in preparing students for organizing game activities in teaching physics is independent work on the application of theoretical knowledge in order to develop tasks for training games. These tasks are developed by small groups of students and presented at laboratory and seminars on the methods of teaching physics, where they are discussed. Students develop such tasks on all topics of the school curriculum in physics. In the methodological "piggy bank" of students, didactic materials are accumulated, which they can use when developing scenarios for role-playing and business games. At the final stage, the teacher's playing position and his focus on play are improved and developed, the development of methods of creative play activity and the operation of play, the upbringing of subjective personality traits.

In a lecture course on the methods of teaching physics, students are introduced to the classification of didactic games. The most used in the practice of teaching physics are:

- training games: dominoes, bingo, crosswords, puzzles, board games, story-tasks, etc .;

- role-playing games: situational tasks, creative educational projects, press conferences, disputes, dramatizations, etc.;

- cognitive and control games: entertaining quizzes, tests, etc.

\section{Conclusion}

The content of games should correspond to the goals of learning, carry an appropriate content load, diversify teaching methods, increase the activity and independence of students. The organization of games requires the preliminary creation of didactic materials, the development of methods for their use.

The content of pedagogical training is mainly focused on the mastery by students of the methods of organizing training, built on a play basis in the study of disciplines of the pedagogical cycle, optional disciplines, passing different types of educational and industrial practices, writing term papers and theses, in the course of educational work and the activities of student self-government. An important condition for achieving the goals of the classes conducted within the framework of such training is the understanding by students of the need to construct subject-subject relations.

Thus, play activity is not only the basis for organizing training, but also a tool for studying its effectiveness, as well as a means of forming student interactivity.

\section{REFERENCES}

1. Borzenkov V.L. Pedagogical game technology. Methodology. Theory. Practice / V.L. Borzenkov // Monograph. -M.: AMBagro, 2000. p 173. 
CURRENT RESEARCH JOURNAL OF PEDAGOGICS 2(8): 52-57, August

2021 DOI: https://doi.org/10.37547/pedagogics-crjp-02-08-12

ISSN 2767-3278

(C)2021 Master Journals

Crossref do: 81 Google

Accepted $26^{\text {th }}$ August, 2021 \& Published 31 th August, 2021

2. Karlybaeva G.E. Use of innovative technologies in the training of future teachers // Bulletin of the National University of Uzbekistan. - Tashkent, 2018. №1 / 3. - B. 228-229.

3. Karlybaeva G.E. Activation of methodical training of future physics teachers through didactic games // Teacher and continuous education. - Nukus, 2018. -№2. - B.114-116.

4. Chechel I. D. Management of research activities of a teacher and student in a modern school. Issue 7 / Library of the School Director magazine. -M., 1998.

5. MUKHIDDINOV, M., SULAYMONOV, I., KHASANOVA, M., ASLANOVA, K., \& SHOMURODOVA, S. (2021). Ode genre and ideological-artistic features of erkin vahidov's odes. Journal of Contemporary Issues in Business and Government, 27(3), 1317-1323.

6. Karlibaeva, G. E. (2021). FORMING RESEARCH COMPETENCIES IN FUTURE PHYSICS TEACHERS. Berlin Studies Transnational Journal of Science and Humanities, 1(1.5 Pedagogical sciences).

7. Муслихиддин, М. К. (2021). THE VIRTUE OF THE WORD. ALISHER NAVOIY XALQARO JURNALI, 1(1).

8. Kuchkarova, M. O. TEACHING A COURSE IN THEORETICAL PHYSICS ACCORDING TO THE PRINCIPLE OF CONTINUITY.

9. Nazmiya, M. (2019). IDEALOGICALARTISTIC CONCERN IN THE CREATION OF KHUSROW DEHLAVI AND ALISHER NAVOI. Глобус, (9 (42)).

10. Erdyneeva, K. G., Nikolaev, E. L., Azanova, A. A., Nurullina, G. N., Bogdanova, V. I., Shaikhlislamov, A. K., ... \& Khairullina, E. R. (2016). Upgrading educational quality through synergy of teaching and research.
International Review of Management and Marketing, 6(1).

11. Muhitdinova, N. M. (2021). Interpretation of mystical themes in Mirhasan Sadoi and muhammad ghazi's collection of poems. Asian Journal of Multidimensional Research (AJMR), 10(3), 538-548.

12. Amirova, A., Buzaubakova, K., Kashkynbayeva, Z., Yelubayeva, M., Kumisbekova, Z., Elmira, U., \& Genc, Z. (2018). Training the creative competence of future teachers.

13. Muhiddinov, M. (2005). The perfect man is the ideal of literature. Tashkent: Yangi asr avlodi, 206. 